\title{
Coagulation Factor IX
}

National Cancer Institute

\section{Source}

National Cancer Institute. Coagulation Factor IX. NCI Thesaurus. Code C28482.

Coagulation factor IX (461 aa, $\sim 52 \mathrm{kDa}$ ) is encoded by the human F9 gene. This protein plays a role in the intrinsic pathway of blood coagulation through the mediation of proteolysis that converts factor $\mathrm{X}$ into an active protease. 